\title{
A Tribute to Kenneth William Stewart, 1936-2011
}

\author{
Francis R. COOK
}

Curator Emeritus and Research Associate, Canadian Museum of Nature, Ottawa, Ontario K0G 1R0 Canada; email: frcook @ripnet.com

Cook, Francis R. 2014. A tribute to Kenneth William Stewart, 1936-2011. Canadian Field-Naturalist 128(1): 84-90.

Kenneth William Stewart, Manitoba herpetologist and ichthyologist, died at Victoria General Hospital in Winnipeg, Manitoba, on 4 July 2011 after an extended battle with the H1N1 virus. Ken was born 30 December 1936 in Madison, Wisconsin, to Drs. John and Gertrude Stewart. Growing up in Clinton, Iowa, he spent much of his youth developing a passion for fishing and nature on the waters of the Mississippi River (Figure 1). He earned a B.Sc. in Dendrology from the Colorado State College of Agriculture and Mechanic Arts (renamed Colorado State University in 1957), Fort Collins, Colorado; an M.Sc. in Marine Biology from the University of Miami, Coral Gables, Florida; and a Ph.D. in Zoology from the University of British Columbia, Vancouver, with a thesis on hybridization between two species of minnow in different genera. Bessie Wenzel (born 1 April 1939) married Ken in Bessie's birth place of Camanche, Iowa, 11 September 1956. Bessie assisted him on many of the field trips during his student years at UBC and was one of the lucky souls to decipher his hand-writing in order to type up his dissertations.

In July 1966, Ken accepted a position in the Department of Zoology at the University of Manitoba as Assistant Professor. From his arrival, he made a major contribution to the remarkable student and staff fellowship of a largely newly recruited zoology department under Harold Welch. Welch had been lured away from the federal Department of Agriculture in the mid-1960s with the challenge of expanding the department, and had quickly blended established researchers like the recently added Casimir Lindsey and veterans like George Lubinsky and Fred Ward, with a bunch of newly minted Ph.D.s from various sources that included, besides Stewart, Mike Aleksiuk, Roger Green, Jack Gee, Roger Evans, and, shortly after, the established W. O. (Bill) Pruitt and others.

"Do ye ken Dr. Stewart at the break of day" (the refrain from a rollicking rendition of an old Scottish melody laced with laudatory original verses depicting Ken's return from all-night frog collecting) still rings heartily in my ears as I write this, decades later. This occasion was an introduction for a departmental seminar presentation by Ken in the winter of 1968-1969 on the developing results of his frog research in Manitoba. This introduction was in partial retaliation for one by Ken for an earlier seminar by Cas Lindsey. Like many endeavours in the zoology department of the University

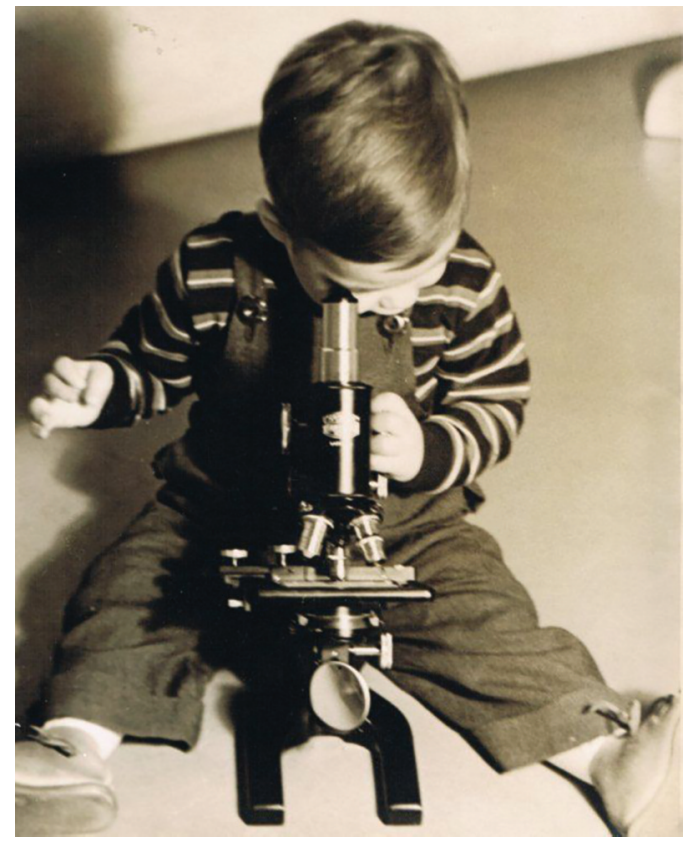

FIgURE 1. A young Ken Stewart: beginnings of a lifetime of scientific curiosity at about 1 or 2, probably at Madison, Wisconsin about 1938. Photo: Stewart family album.

of Manitoba at the time, it originated with Lindsey inciting the collaboration of a crew of enthusiastic younger professors and graduate students. This model department generated fresh excitement and productivity virtually daily, a utopia for a student. Not the least in creating this atmosphere of fellowship in the zoology department were the sometimes scathing and always humorous and good-natured barbs contributed by Ken, whose presence ensured that no one lost perspective. Ken was also an enthusiastic participant in (and sometimes victim of) the annual departmental Christmas party skits, where students and professors parodied each other, a tradition brought from the University of British Columbia by Lindsey and his former students.

In 1972, Ken was promoted to Associate Professor and in 1984 to Professor. He retired in 2000 after teaching for 34 years. He gave courses on the biology of fishes, the biology of amphibians and reptiles, the prin- 
ciples and process of evolution (jointly with B. J. Hann), the ethics and principles of animal care, and an introduction to chordate zoology. On retirement, he was appointed a Senior Scholar at the University of Manitoba.

Former student Doug Watkinson who co-authored The Freshwater Fishes of Manitoba, providing 100 of the 160 photographs commented: "Ken had an amazing memory and was able to cite the Latin names of fishes from all over the world. He was interested in many different fields of science; I know physics was one of his favourite reading topics. I guess another way of putting it is he had a tremendous breadth and depth of knowledge on numerous topics. He loved to teach and was a great story teller. When you were in one of your classes you felt inspired by his passion on the topic. He really seemed to enjoy the people he worked with and the students. He was an avid outdoors person, enjoying fishing and hunting whenever he could find the time. He was keen to share a fishing trip with new University staff and students in his boat on the Red River. If the person did not fish at all that was often all the more reason to take them out. Really he was generous both with his time and sharing his pastime. He had no fear of ethanol, isopropanol or formaldehyde and the possible effects they had on his skin. It was very typical for him to plunge his hands and arms into a vat of fish with 20 year old isopropanol running into his shirt and dripping on his pants. His office was a disorganized disaster to look at but if you asked him for something he would instantly reach into the piles of papers and pull out what he needed. In contrast to his office organization he was meticulous with his notes on whatever project he was working on."

Another former student Gavin Hanke recalls that Ken's lectures on anatomy and lab discussions included tests of attention by mention of the foramen Remington (i.e., bullet holes) in skulls. Gavin also recalled, "Rarely was Ken tricked in return, but it did happen, and he took it with the usual humour we knew to expect. On one occasion he boldly stated that only the extinct acanthodian fishes had pectoral fin spines. Then a student pointed out that his favourite fishing quarry (Channel Catfish) had pectoral fin spines. The look on Ken's face was priceless," as was his response. His early lectures annually featured a guest lecture by Cas Lindsey to present his classic paper on the phylogeny of dragons to demonstrate classification methods.

Ken was an active participant in many zoology department and university committees, developing guidelines as a member (later chair) of animal care and serving on committees at the University of Manitoba and representing it on interuniversity committees throughout his tenure. Included in his other committee contributions was membership and later chair of zoology curriculum review committees.

Ken was also interested in reaching out to the public. $\mathrm{He}$ presented lectures and demonstrations related to amphibian and reptile biology at primary and secondary schools, Manitoba Schools Science Symposium, and community organizations, such as Scouts, averaging 12 per year; he made major contributions to conservation in Manitoba by conducting tours of Red-sided Gartersnake (Thamnophis sirtalis parietalis) dens in the Interlake district for the Manitoba Naturalists Society (now Nature Manitoba) every year; he was an advisor to the British Broadcasting Corporation on Gartersnake (Thamnophis sirtalis) biology during the production of David Attenborough's "Life on Earth" series (approximately 5-minute portion of programme 5 ) and he was an advisor to film crews from the Canadian Broadcasting Corporation and the Royal Ontario Museum on Gartersnake biology for the production of educational films. He presented interpretive lectures for Manitoba Provincial Parks on Manitoba amphibians and reptiles (Spruce Woods Provincial Park 19811991). He served as advisor to the provincial Wildlife Branch on amphibian and reptile biology in 1971-1972 on the status of and protection extended to amphibians and reptiles by revision of the Wildlife Act; in 1972 and subsequently, he provided continuing advice on the regulation of the commercial harvest of Gartersnakes and Northern Leopard Frogs (Lithobates pipiens) during a period when biological supply houses were intensively harvesting from the large populations of these species in Manitoba; with the Manitoba Naturalists, he advised on the protection of communal Red-sided Gartersnake dens at Narcisse, where a cluster of dens was designated a Provincial Wildlife Management Area; he advised the Manitoba Conservation Data Centre on the status of fish, amphibian, and reptile species in Manitoba; in 1989 and after, he advised the Wildlife and Fisheries branches regarding control of nesting Double-crested Cormorant (Phalacrocorax auritus) populations on Lake Winnipegosis.

During the two years (1968-1970) I spent in Winnipeg, to fulfill the university residence requirement for a Ph.D., and afterward, when I returned to the National Museum of Canada to complete my thesis (among my other duties), Ken doggedly supported my efforts, and the degree was finally obtained in 1978. As a Ph.D. supervisor, Ken was ideal, always generating suggestions for additional approaches and then leaving the student the independence to decide what advice to take and what to use of his own ideas. But he allowed little argument over ruthlessly cutting the verbosity in his students' theses drafts. (If Ken were alive, this tribute would be a fraction of its present length.)

Ken joined field trips with awesome enthusiasm. I recall these with special relish for the successes and comradeship as we investigated the fascinating biological transition zone east of Winnipeg to the Ontario border. Ken and I vied, often separately, in nightly spring outings to plug holes in our understanding of Manitoba amphibian distribution, especially the distribution of call types ("species") of the Gray Treefrog (Hyla versicolor). Each morning in the lab, we would 
exchange our latest respective successes and individual theories and differing interpretations. He also promoted seldom studied winter herpetology by in-season scuba diving for Mudpuppies (Necturus maculosus) in the waters of the Brokenhead River and skidooing on frozen Lake Manitoba to investigate the Leopard Frogs found in the bottom meshes of fisher's nets far out from shore. Jim Johnston took his B.Sc. at the University of Manitoba and was Ken's field assistant until he accepted an offer to be herpetological technician at the National Museum of Natural Sciences in 1972. He stayed until 1979, when his interest in photography led to a position with the Canadian Museum of Science and Technology.

Patrick Gregory arrived in Manitoba a year after I did, after completing his B.Sc. at the University of Toronto. He left with not only a master's degree (1971) but also a doctoral degree (1973), both based on research assisted by the Great Dane Jason on the incredible Redsided Gartersnake dens in the Interlake area, until then unstudied. It is a tribute to Ken's stimulating role as supervisor that Gregory, Tom Vincent (M.Sc., 1971), and Don Hart (M.Sc., 1975) completed graduate degrees based on snake populations from this area (four theses; eight publications) (Figure 2). Subsequently, Vincent continued his Interlake snake studies in a Ph.D. thesis under Diane Secoy at the University of Regina. Further, Ken interested departmental colleague and physiologist Mike Aleksiuk in the Red-sided Gartersnakes, and Mike with his students added another 14 papers. Then David Crews from Harvard University with Mike Garstska and other students subsequently analyzed the behaviour, pheromones, and other aspects of the Red-sided Gartersnake to extend studies there by over 30 additional papers. Gregory went on to the University of Victoria, where he remains to this day as Professor, with a term served as department head and a succession of papers and students extending the studies of Gartersnake ecology to British Columbia, Alberta, and the Northwest Territories and to other snakes, turtles, and even salamanders and frogs from British Columbia.

Ken did have other graduate students in reptiles and amphibians after Pat and me, so it is untrue that shepherding the two of us to doctorates completely wore out his enthusiasm for herpetology. His change in emphasis was more likely triggered by the departure of ichthyologist Cas Lindsey, who returned to the University of British Columbia. After that, Ken resumed work on his initial interest, fish (even including some palaeontology - a true measure of versatility and flexibility). Former graduate student Gavin Hanke has pointed out that it was fitting that Ken's paleontological interests focused on fishes from the Devonian, the Age of Fishes. A succession of papers and graduate students followed for these lower vertebrates, and Ken extended his field experience occasionally beyond Manitoba with trips to Fiji and Africa.

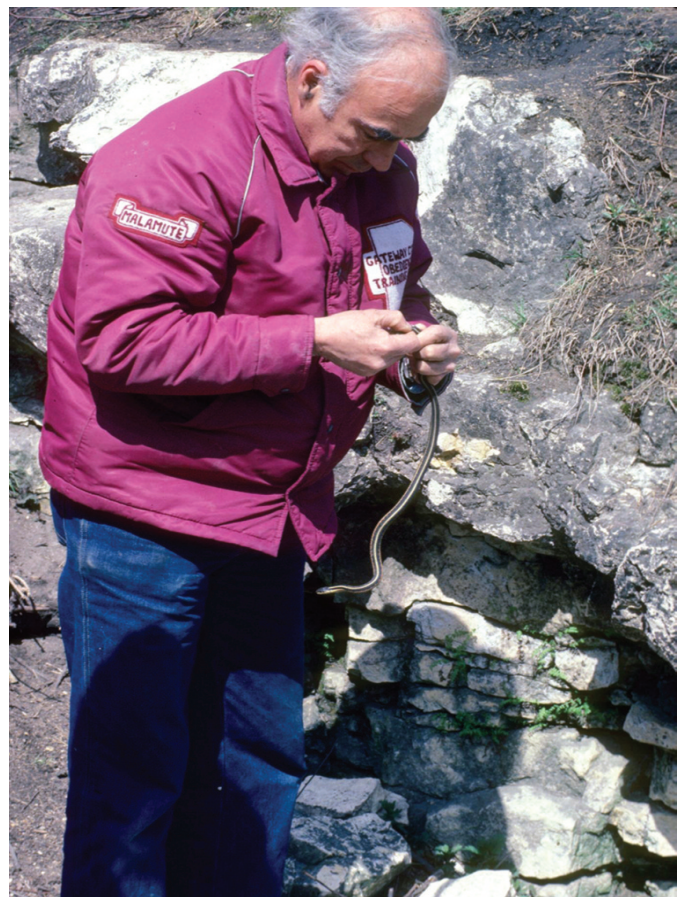

FIGURE 2. Ken Stewart at a Red-sided Garter Snake (Thamnophis sirtalis parietalis) den in the Interlake region, April 1983. Photo: D. Berezanski.

Though brought up farther south and with only an initial introduction to Canada in British Columbia, Ken embraced the shockingly different climate of Manitoba with the same unnerving cheer with which he met any challenge. He added a brace of Malamutes (a breed of Huskies he had come to admire during vacation fishing trips to the Northwest Territories) to his family. These dogs were regularly harnessed to sleds he built himself in the traditional native way. Ken drove them on the streets in his residential Winnipeg suburb and beyond to the surrounding windswept spaces most of us avoided from October until April.

Ken and I shared a commitment to dogs (though we differed greatly on breeds favoured), but Ken drew a personal line on cats. He never could gain acceptance by Tasha, our independent-minded Siamese, who may have realized this, as she invariably quietly welcomed his visits by jumping up on the couch beside him and biting him under the arm. It was a measure of his tolerance that he invariably took this with good humour and restraint, although not without increasing apprehension.

Along with Bessie, he furthered our education beyond herpetology by cooking up batches of fresh-caught local crayfish and catfish (Figure 3) and treating my wife, Joyce, and I to feasts on these. Ken relished both; a taste brought north from his early upbringing in the Mississippi drainage. But I missed out on his sausage-making, 


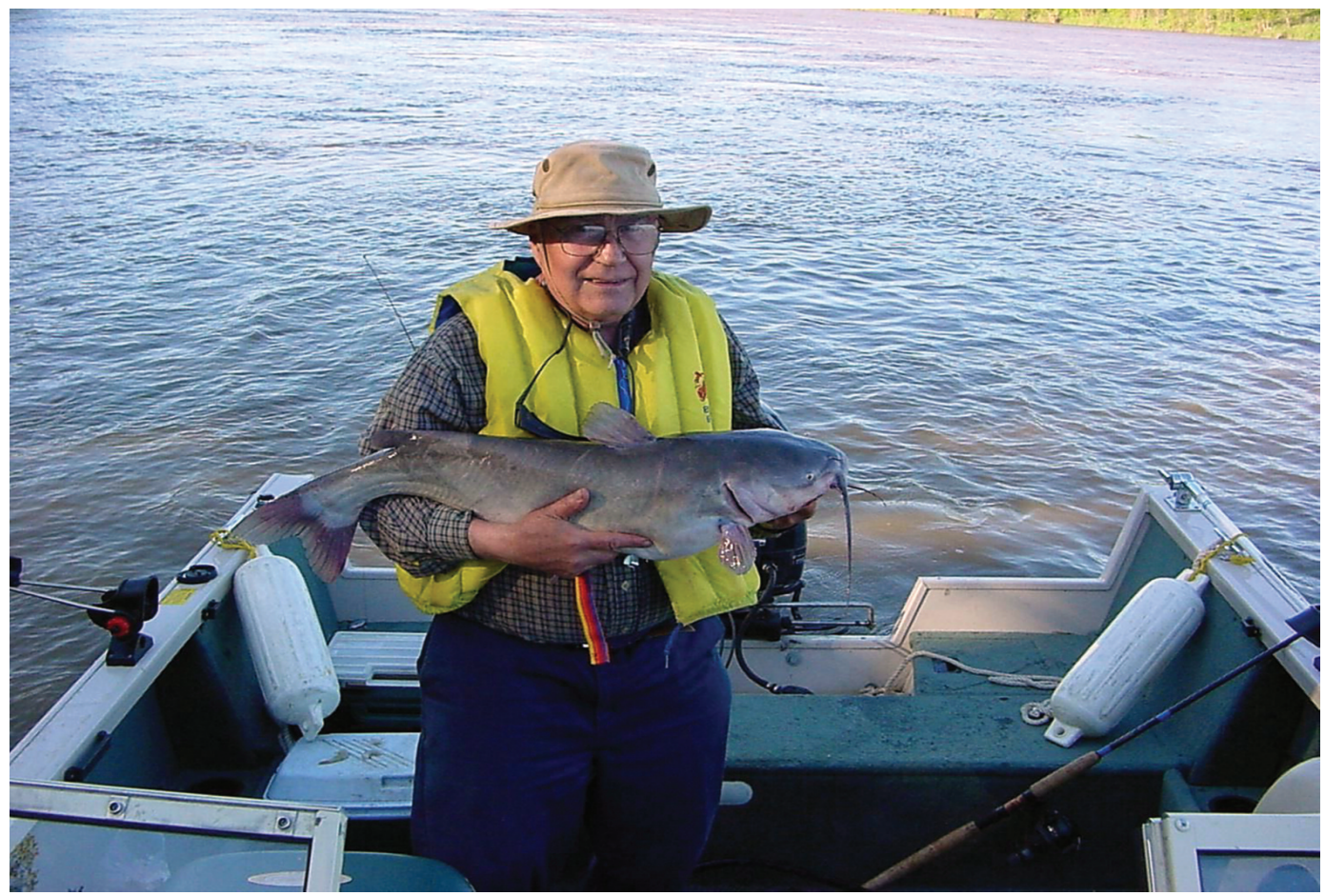

FIgURE 3. Ken Stewart and Channel Catfish (Ictalurus punctatus) on the Red River. Photo: Stewart family.

for which Pat Gregory vividly recalls a session : "Ken attached 20 feet (or so) of sheep intestine to a (manual, I think) meat grinder, into which he put his previously prepared mix of sausage meat and seasoning, etc. As the grinder worked away, the sausage mix was forced into the intestine, so Ken had to quickly move to the output end of the machine to twist the lengthening coil here and there to form sausage links. The links were all of different lengths and the whole chain seemed to slowly wind its way around the kitchen like some invading organism."

Cas Lindsey has summed up Ken's contributions: "Ken was a man with a wide range of interests, which he pursued with impressive expertise. Amongst his colleagues and his students he was the accepted source for astonishingly well-informed opinion on almost any topic. He was as versatile in his skills as in his written knowledge; in subtropical seas he was a highly competent scuba diver; in subarctic (Winnipeg) climes he reared husky dogs. He was a mine of information on the academic side of ichthyology, but he was also a skilled and enthusiastic angler. He loved hunting as well as fishing, and he knew a great deal about guns. (He even constructed a firing range in the basement of his Winnipeg home.) Despite his great store of knowledge, he was singularly modest and uncompetitive. Disinterested in self-aggrandizement, Ken preferred teaching to writing. He did not often publish through- out most of his teaching career. But fortunately in 2004 he more than made up for a slow start, and poured a cornucopia of experience into the authoritative and attractive volume The Freshwater Fishes of Manitoba (K. W. Stewart and D. A. Watkinson, University of Manitoba Press) (Figure 4). Although this may not be the best way to get NSERC [Natural Sciences and Engineering Research Council of Canada] grants, the book demonstrates there is much to be said for writing your great book after you have built up years of experience, rather than the other way around."

Ken and I remained in touch through correspondence and during occasional visits Ken made to Ottawa. I often called on Ken for perceptive and constructive reviews of papers on fish, reptiles, and amphibians when I served as chair of the Committee on the Status of Endangered Wildlife in Canada (COSEWIC) Subcommittee on Amphibians and Reptiles and as editor of The Canadian Field-Naturalist.

Ken is survived by his wife, Bessie, of Winnipeg, daughters Kathy (Guy) Plett of Winnipeg and Anne (Rob) Moniuk of Oakville, Ontario, and son John Stewart of Vancouver, British Columbia. Ken also leaves grandchildren Elizabeth (Don Ross) Plett, Guy Plett, Wendy Moniuk, and Victor Moniuk, and greatgrandchildren William and Cameron Plett and Alyssa and Ella Ross. A memorial was held in his honour on 8 October 2011 at the University of Manitoba. 


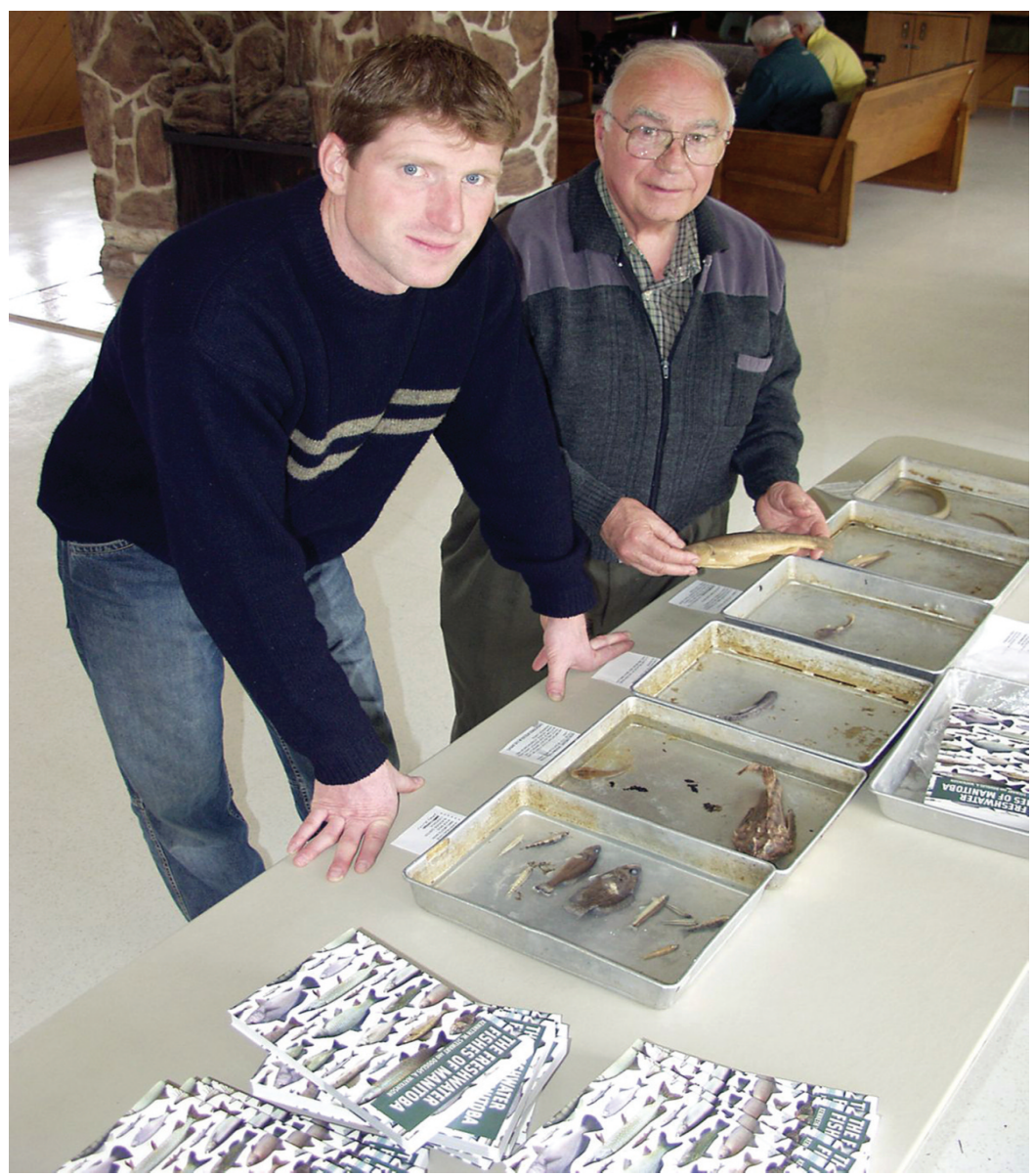

Figure 4. Ken Stewart (right) and coauthor D. A. Watkinson at the media book launch for The Freshwater Fishes of Manitoba in 2004. Photo: University of Manitoba Press.

\section{Acknowledgements}

An obituary appeared in the Winnipeg Free Press, 6 July 2011. Appreciation is owed to C. C. Lindsey, Gavin Hanke, Patrick Gregory, Doug Watkinson, and Beverly Horn for their recollections. Darren Gillis, at the University of Manitoba, and Ken's daughters Anne Moniuk and Kathy Plett contributed photographs and further information. D. A. Watkinson advised on contacts and he and Bruce McCulloch provided additional documentation for photographs.

\section{Bibliography of Kenneth William Stewart}

\section{Publications}

Stewart, K. W. 1962. Observations of the morphology and optical properties of the adipose eyelid of fishes. Journal of the Fisheries Research Board of Canada 19(6): 1161-1162.

Peden, A., and K. W. Stewart. 1964. Extension of the known range of the antherinid fish Atherinops affinis. Copeia 1964(1): 239-240.

Stewart, K. W., and C. B. Levin. 1968. A method of obtaining permanent dry mounted chromosome preparations from fish. Journal of the Fisheries Research Board of Canada 25(5): 1091-1093.

Lane, E. D., and K. W. Stewart. 1968. A revision of the genus Hoplunnis Kaup (Apodes, Muraenesocidae), with a description of a new species. Contributions in Marine Science (Marine Science Institute, University of Texas, Port Aransas, Texas) 1968 (13): 51-64.

Stewart, K. W., and C. C. Lindsey. 1969. First specimens of the stonecat, Noturus flavus, from the Hudson Bay drainage. Journal of the Fisheries Research Board of Canada 27(1): $170-172$.

Stewart, K. W., and F. R. Cook. 1970. [Abstract] Distribution of tree frogs of the Hyla versicolor complex in Manitoba. Pages 27-28 in American Society of Ichthyologists and Herpetologists Fifteenth Annual Meeting Abstracts, New Orleans, Louisiana, 26-30 March 1970. Tulane University, New Orleans, Louisiana.

Aleksiuk, M., and K. W. Stewart. 1971. Seasonal changes in the body composition of the garter snake (Thamnophis sirtalis parietalis) at northern latitudes. Ecology 52(3): 485490. 
Gregory, P. T., and K. W. Stewart. 1975. Long distance dispersal and feeding strategy of the red-sided garter snake (Thamnophis sirtalis parietalis) in the Interlake of Manitoba. Canadian Journal of Zoology 53(3): 238-245.

Stewart, K. W., and C. C. Lindsey. 1983. Postglacial dispersal of lower vertebrates in the Glacial Lake Agassiz region. Pages 391-419 in Glacial Lake Agassiz. Edited by J. T. Clayton and L. Clayton. Geological Association of Canada Special Paper 26. Geological Association of Canada, c/o Memorial University of Newfoundland, St. John's, Newfoundland and Labrador.

Stewart, K. W. 1984. Maintenance of captive reptiles. In Care and Use of Experimental Animals: A Guide for Canada, Vol. II. Edited by F. H. Flowers and J. P. W. Gillman. Canadian Council on Animal Care, Ottawa, Ontario.

Stewart, K. W. 1984. Maintenance of captive amphibians. In Care and Use of Experimental Animals: A Guide for Canada, Vol. II. Edited by F. H. Flowers and J. P. W. Gillman. Canadian Council on Animal Care, Ottawa, Ontario.

Stewart, K. W., I. M. Suthers, and L. K. Leavesley. 1985. New fish distribution records in Manitoba and the role of man-made interconnection between two drainages as an avenue of dispersal. Canadian Field-Naturalist 99(3): 317 326.

Hubicht, S. M., W. G. Franzin, and K. W. Stewart. 1988. New distributional records for the minnows Hybognathus hankinsoni, Phoxinus eos, and P. neogaeus in Manitoba. Canadian Field-Naturalist 102(3): 475-484.

Stewart, K. W. 1988. First collections of the weed shiner, Notropis texanus, in Canada. Canadian Field-Naturalist 102(4): 657-660.

Stewart, K. W., and C. Lindsey. 1990. Report to Fort Whyte Outdoor Education Centre on Fish Species Composition and Management Recommendations for the Fort Whyte Ponds. August, 1990.

Stewart, K. W. 1990. Preliminary Assessment of the Impact of the Dam on the Red River Proposed in the Pembina Triangle Water Supply Study on Fish Communities in the Red River. Submitted to the Manitoba Department of Natural Resources and to the Manitoba Environmental Council, October 1990.

Campbell, K. B, A. J. Derksen, and K. W. Stewart. 1991. First specimens of the Rainbow Smelt, Osmerus mordax, from Lake Winnipeg. Canadian Field-Naturalist 105(4): 568-570.

Hanke, G. F., and K. W. Stewart. 1994. Evidence for recent dispersal of fishes in Lake Winnipeg. Proceedings of the North Dakota Water Quality Symposium, Part III: 133-149.

Duncan, J., E. Bredin, G. Hanke, W. Koonz, R. Larche, K. Leavesley, W. Preston, D. Ross, C. Scott, D. Stardom, K. Stewart, and P. Taylor. 1994. Estimated status of Manitoba amphibians based on criteria used by the Nature Conservancy's Conservation Data Center Network. Proceedings of the 4th Meeting of the Task Force on Declining Amphibian Populations in Canada, Part IV: 93-103.

Hanke, G. F., K. W. Stewart, and G. A. Lammers. 1996. Eastmanosteus lundarensis, a new arthrodire from the Elm Point Formation of Manitoba. Journal of Vertebrate Paleontology 16(4): 606-616.

Hanke, G. F., K. W. Stewart, and G. A. Lammers. 1996. Squamatognathus steeprockensis, a new inferognathal from the Elm Point Formation of Manitoba. Journal of Vertebrate Paleontology 16(4): 617-622.

McCulloch, B. R., and K. W. Stewart. 1998. Range extensions and new locality records for the stonecat, Noturus flavus, in Manitoba: evidence for a recent natural invasion. Canadian Field-Naturalist 112(2): 217-224.

Steinhilber, M., and K. W. Stewart. 1999. The species diversity of fishes in the Prairies Ecozone of Canada. Report Commissioned by Environment Canada.

Stewart, K. W., W. G. Franzin, B. R. McCulloch, and G. F. Hanke. 2001. Selected case histories of fish species invasions into the Nelson River system in Canada. Pages 63-81 in Science and Policy: Interbasin Transfer of Aquatic Biota. Edited by J. A. Leitch and M. J. Tenamoc. Institute for Regional Studies, North Dakota State University, Fargo, North Dakota.

Franzin, W. G., K. W. Stewart, G. F. Hanke, and L. Heuring. 2003. The fish and fisheries of Lake Winnipeg: the first 100 years. Canadian Technical Report of Fisheries and Aquatic Sciences 2398. Central and Arctic Region, Department of Fisheries and Oceans, Winnipeg, Manitoba. 53 pages.

Stewart, K. W., and D. A. Watkinson. 2004. The Freshwater Fishes of Manitoba. University of Manitoba Press, Winnipeg, Manitoba. 276 pages.

Theses supervised

Schweitzer, R. D. 1968. Evidence of two sympatric forms of ciscoes (subgenus Leucichthyes) in Cedar Lake. M.Sc. thesis, University of Manitoba, Winnipeg, Manitoba.

Case, B. E. 1970. An ecological study of the tadpole madtom, Noturus gyrinus (Mitchell), with special reference to movements and population fluctuations. M.Sc. thesis, University of Manitoba, Winnipeg, Manitoba.

Gregory, P. T. 1971. Overwintering populations and homing of the red-sided garter snake (Thamnophis sirtalis parietalis) at a northern latitude. M.Sc. thesis, University of Manitoba, Winnipeg, Manitoba.

Vincent, T. K. 1971. Resistance to cold stress in the red-sided garter snake (Thamnophis sirtalis parietalis) at a northern latitude. M.Sc. thesis, University of Manitoba, Winnipeg, Manitoba.

Levin, C. B. 1972. Karyotypic analysis of somatic chromosomes of Noturus gyrinus (Mitchell) (Ictaluridae: Teleostei). M.Sc. thesis, University of Manitoba, Winnipeg, Manitoba.

Gregory, P. T. 1973. Life history parameters of a population of red-sided garter snakes (Thamnophis sirtalis parietalis) adapted to a rigorous and fluctuating environment. Ph.D. thesis, Univiversity of Manitoba, Winnipeg, Manitoba.

Clarke, R. McV. 1973. Systematics of ciscoes (Coregonidae) in central Canada. Ph.D. thesis, University of Manitoba, Winnipeg, Manitoba.

Hart, D. R. 1975. Quantitative niche comparison of the western plains garter snake (Thamnophis radix haydeni) and the red-sided garter snake (Thamnophis sirtalis parietalis) in allopatric and sympatric regions of Manitoba's Interlake District. M.Sc. thesis, University of Manitoba, Winnipeg, Manitoba.

Eddy, S. B. 1976. Population ecology of the leopard frog, Rana pipiens pipiens Schreiber, at Delta Marsh, Manitoba. M.Sc. thesis, University of Manitoba, Winnipeg, Manitoba.

Cook, F. R. 1978. An analysis of toads of the Bufo americanus group in a contact zone in central North America, Ph.D. thesis, University of Manitoba, Winnipeg, Manitoba.

Yaremchuk, G. 1981. The effects of exposure to predation on mean vertebral and fin ray counts in the fathead minnow (Pimephales promelas). M.Sc. thesis, University of Manitoba, Winnipeg, Manitoba. 
Guinn, B. 1982. A morphological and ecological comparison of round whitefish (Prosopium cylindraceum) and mountain whitefish (P. williamsoni) in allopatric and sympatric areas in northwestern Canada. M.Sc. thesis, University of Manitoba, Winnipeg, Manitoba.

Day, A. C. 1982. Ecology of burbot, Lota lota and lake trout, Salvelinus namaycush in Lake Athapapuskow, Manitoba. M.Sc. thesis, University of Manitoba, Winnipeg, Manitoba.

Leavesley, L. K. 1987. Ecological study of the western hognose snake, Heterodon nasicus nasicus in Spruce Woods Provincial Park, Manitoba. M.Sc. thesis, University of Manitoba, Winnipeg, Manitoba.

Wallace, R. 1989. Multivariate analysis of habitat parameters affecting occurrence, abundance and productivity of lake trout, Salvelinus namaycush, in lakes in northern Saskatchewan. M.Sc. thesis, University of Manitoba, Winnipeg, Manitoba.

Harbicht, S. A. 1990. Biology of the shorthead redhorse, Moxostoma macrolepidotum in Lake Dauphin, Manitoba. M.Sc. thesis, University of Manitoba, Winnipeg, Manitoba.

Horn, B. M. 1993. Geographic variation of populations of Mimic Shiners, Notropis volucellus (Cope 1865) and Sand Shiners, Notropis stramineus stramineus (Cope 1865) (Cyprinidae), in Manitoba and southern Ontario. M.Sc. thesis, University of Manitoba, Winnipeg, Manitoba.

Rowes, K. D. 1994. Temporal and spatial distribution of pelagic larval fishes of Dauphin Lake, Manitoba. M.Sc. thesis, University of Manitoba, Winnipeg, Manitoba.

McCulloch, B. 1994. Dispersal of the Stonecat (Noturus flavus) in Manitoba and its interactions with resident fish species. M.Sc. thesis, University of Manitoba, Winnipeg, Manitoba.

Ogutu-Ohwayo, R. 1994. Adjustments in fish stocks and in life history characteristics of the Nile Perch, Lates niloticus L. in Lakes Victoria, Kyoga and Nabugabo. Ph.D. thesis, University of Manitoba, Winnipeg, Manitoba.

Doolgindachbaporn, S. 1994. Development of optimal rearing and culturing systems for the Climbing Perch, Anabas testudineus (Bloch) (Perciformes, Anabantidae). Ph.D. thesis, University of Manitoba, Winnipeg, Manitoba.

Johnson, J. D. 1995. Description and comparison of two populations of Saffron Cod (Eleginus gracilis) from western Canadian Arctic coastal waters. M.Sc. thesis, University of Manitoba, Winnipeg, Manitoba.

Tyson, J. D. 1996. The effect of thermal effluent on overwintering Channel Catfish (Ictalurus punctatus) in the lower Red River, Manitoba. M.Sc. thesis, University of Manitoba, Winnipeg, Manitoba.

Hanke, G. 1996. A survey of the fishes of Lake Winnipeg and interactions of the introduced White Bass with the native ichthyofauna of Hudson Bay drainage: with emphasis on young-of-the-year in nearshore environments. M.Sc. thesis, University of Manitoba, Winnipeg, Manitoba.

Stephenson, S. A. 1996. An analysis of meristic, morphometric and biochemical variation in the Johnny Darter, Etheostoma nigrum Rafinesque, in the northern United States and Canada with biogeographic and systematic considerations. M.Sc. thesis, University of Manitoba, Winnipeg, Manitoba.

Kristofferson, A. H. 2003. Identification of Arctic char stocks in the Cambridge Bay area, Nunavut Territory and evidence of stock mixing during overwintering. Ph.D. thesis, University of Manitoba, Winnipeg, Manitoba.

Publications arising from graduate student research that Stewart supervised or advised

(in chronological order)

Hlynka, L. 1969. The biology of Rana pipiens Schreber and Bufo hemiophrys Cope in the Delta marshes. University of Manitoba Delta Marsh Field Station report.

Hlynka, L. J. 1970. Helminths in Rana pipiens Schreber, and Bufo hemiophrys Cope, from the Delta Marshes, Manitoba. M.Sc. thesis, Department of Zoology, University of Manitoba. 110 pages. (Supervisor, G. Lubinsky)

Aleksiuk, M., and P. T. Gregory. 1974. Regulation of seasonal mating behaviour in Thamnophis sirtalis parietalis. Copeia 1974(3): 681-89.

Gregory, P. T. 1974. Patterns of spring emergence of the redsided garter snake (Thamnophis sirtalis parietalis) in the Interlake region of Manitoba. Canadian Journal of Zoology 52(8): 1063-69.

Gregory, P. T. 1977. Life-History Parameters of the Redsided Garter Snake (Thamnophis sirtalis parietalis) in an Extreme Environment, the Interlake Region of Manitoba. National Museums of Canada, Ottawa, Ontario. 44 pages.

Hart, D. R. 1979. Niche relationships of Thamnophis radix haydeni and Thamnophis sirtalis parietalis in the Interlake District of Manitoba. Tulane Studies in Zoology and Botany 21: $125-140$.

Hart, D. R. 1982. Growth of Painted Turtles, Chrysemys picta, in Manitoba and Louisiana. Canadian Field-Naturalist 96: 127-131.

Cook, F. R. 1983. An analysis of toads of the Bufo americanus group in a contact zone in central northern North America. National Museum of Natural Sciences, National Museums of Canada, Ottawa, Ontario. 89 pages.

Received 27 October 2013

Accepted 21 February 2014 